sary to investigate the behaviour of $\gamma$ during periods of ancestrus due to retention of the corpus luteum, and this we propose to do.

One of us (A.T.C.) is indebted to the Agricultural Research Council for a grant to undertake these experiments.

G. W. Scoty Blair.

A. T. CowIE.

F. M. V. Coppen.

National Institute for Research in Dairying, University of Reading. May 1. 1 Scott Blair, G. W., Folley, S. .T., Malpress, F. H., and Coppen,
F.M.V., Biochem. J., 35, 1039 (1941); NATURE, 147, 453 (1941). ${ }^{2}$ Scott Blair, G. W., Koll. Z., 78, 19 (1937).

${ }^{3}$ The linearity of such curves for non-Newtonian honey was commented on in ref. (2)

\section{Breakdown of Self-Incompatibility by $\alpha$-Naphthalene Acetamide}

SELF-incompatible Petunia, Tagetes, Trifolium repens and Brassica oleracea have been made selfcompatible by spraying the flowering plants with a solution of $\alpha$-naphthalene acetamide ${ }^{1}$. This new technique has many possibilities to the plant breeder, but without a more complete study of how it works these possibilities cannot be developed properly. Eyster states that " $\alpha$ naphthalene acetamide neutralizes the effects of an ovarian secretion which diffuses into the style and inhibits or greatly retards the growth of pollen tubes". Since there is evidence that incompatibility is due to an immunological reaction between highly specific antigens and antibodies $^{2,3}$, it is improbable that $\alpha$-naphthalene acetamide should be a simple haptene to the incompatibility antibodies of four different genera of plants.

In Prunus avium, I find that $\alpha$-naphthalene acetamide does not increase the rate of incompatible or compatible pollen tube growth, but it does have a profound action on the formation of the abscission layer at the base of the style. Therefore it allows a longer time for the incompatible tubes to reach the ovary. The abscission layer forms two days earlier in untreated and unpollinated or incompatibly pollinated flowers than in flowers treated with $\alpha$-naphthalene acetamide or pollinated with compatible pollen (see accompanying table). We see, therefore, in this case that the action of the $\alpha$-naphthalene acetamide is not to 'neutralize' the incompatibility substances but to supply or replace the anti-abscission hormone which is normally produced by compatible pollen tubes or by the ovule immediately after fertilization.

length of Pollen Tubes after Four Days and the Number OF DAYs TO FORM THE ABSCISSION LAYER IN Prunus avium VAR. BEDFORD PROLIFIC

\begin{tabular}{|l|c|c|c|c|c|c|}
\hline \multicolumn{1}{|c|}{ Pollen } & No treatment & \multicolumn{2}{|c|}{ Water } & \multicolumn{2}{c|}{$\begin{array}{c}\text { Naphthalene } \\
\text { acetamide }\end{array}$} \\
\hline mm. & days & mm. & days & mm. & days \\
\hline $\begin{array}{l}\text { Crossed } \\
\text { Compatible }\end{array}$ & $13^{*}$ & 6 & 13 & 5 & 13 & 7 \\
\hline $\begin{array}{l}\text { Selfed } \\
\text { Incompatible }\end{array}$ & $7 \cdot 1$ & 4 & $6 \cdot 8$ & 3 & $6 \cdot 6$ & 6 \\
\hline None & 0 & 4 & 0 & 4 & 0 & 6 \\
\hline
\end{tabular}

- The $13 \mathrm{~mm}$. incompatible pollinations is an approximation because the tuhes at this time were in the ovary.

Since the $\alpha$-naphthalene acetamide delays abscission for two days, its use may not be confined to removing the bar to self-fertilization but it may decrease inter. specific sterility in plants, especially those with manyseeded fruits. In Prunus avium, unlike Petunia, no fruits were obtained after treatment and self-pollination; it is therefore probable that only plants which have a weak incompatibility reaction will be selffertile after treatment.

John Innes Horticultural Institution,

D. Lewis.

Merton, London, S.W.19. May 2.

${ }^{2}$ Eyster, W. H., Science, 94, 144 (1941).

'Sears, E. R., Genetics, 22, 130 (1937).

${ }^{3}$ Lewis, D., Proc. Roy. Soc., B. (in the press).

\section{Polygenic Inheritance and the Drosophila Culture}

Recentuy Dr. Mather has directed attention to the importance of the study of polygenic inheritance in relation to practical breeding and to the elaboration of evolutionary theory $\mathbf{1 , 2}^{2}$. He has correctly emphasized that failure to study such inheritance lies behind much of biologists' criticism of present-day genetics. However, there is one. other important circumstance which, in our opinion, he has not emphasized sufficiently. It is the relation of environment to heredity ; the problem of nature and nurture.

In the present context the influence of environment on the expression of heredity has a twofold importance. First, since polygenes "have individual effects which are small compared with non-heritable fluctuations"2, it follows that their phenotypic expression (or exhibition) is easily modified by environmental changes or differences. Consequently one of the technical difficulties which prevented genetieists from working in this field was the problem of estimating the separate effects of polygenes and environment on the resulting phenotypes. Present statistical methods, as Hogben has pointed out ${ }^{3}$, do not always adequately overcome these difficulties. This almost certainly led the "Drosophilists" to concentrate on the study of "unit characters", ete., and to neglect the less easily handled genes or groups of genes the expression of which is easily modified by environment.

Secondly, we have shown that the normal Drosophila culture is not an ideal environment for such studies. As such cultures develop, the quality of the yeasts present (the larval food) changes in a more

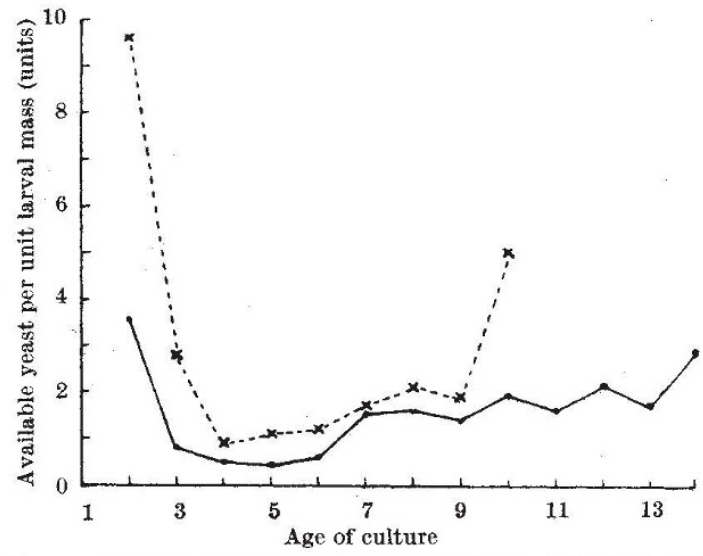

Darly changes of the QUaNTITy OF Yeast aVaILABle PER UNIT MASS IN DROSOPHILA CULTURES CONTAINING ONZ PAIR OF TLITS (UPPER CURVE) AND THREE PAIRS OF FLIES (LOWER CURVE). 